\title{
Combined Effect of Marble Dust and Steel Fiber on the Mechanical Properties of High Strength Concretes
}

\author{
Krishan Kumar \\ M Tech Scholar, Department of Civil Engineering \\ Om Institutes of Technology \& Management, \\ Juglan Hisar, Haryana
}

\section{ABSTRACT}

Present day construction cost is at its height with using basic materials like cement, coarse aggregates and fine aggregates. Leaving waste materials to nature specifically can bring about environmental issues. Therefore, reuse of waste materials has been emphasized. Industries produce lots of waste materials, which might be helpful in partial replacement of basic materials due to their composition and it can be proved economical. The concrete industry is always searching for supplementary material with the target of decreasing the solid waste disposal issue. As we know concrete is weak in tension so, to overcome this, steel fibers has been used. There are few reuse and recycling solutions for this industrial by-product, both in experimental phase and have useful applications. These mechanical wastes are dumped in the close-by areas and natural fruitfulness of the soil is ruined. The physical, mechanical \& chemical properties of wastes are discussed. In this study, marble powder has replaced sand, the whole research is carried out on M60 grade concrete with partly replacing sand by $0 \%$, $15 \%, 30 \%, 45 \%$, and $60 \%$ of marble dust, with the addition of steel fibers at ratio $0.8 \%$ by volume so as to get greatest compressive strength, flexural strength and furthermore split tensile strength. Based upon the feasibility interpretation it is observed that replacing up to $45 \%$ marble powder and $0.8 \%$ of steel fibers in concrete is appropriate in conformance with the requirement. The compressive strength and the spilt tensile increased up to $15 \%$ replacement, after that they started decreasing.

KEYWORDS: steel fibers, marble dust

\section{INTRODUCTION}

The second largest material used by human beings after food and water is Concrete. It is widely used as a

\author{
Sumesh Jain \\ Asst. Professor, Department of Civil Engineering Om \\ Institutes of Technology \& Management, \\ Juglan Hisar, Haryana
}

construction material. It includes cement, fine aggregates, coarse aggregates and water, where the fine aggregates is normally regular river sand. The major component of the concrete is cement. The cement, generally Portland cement and other materials that provide cementitious properties like fly ash and cement slag act as a binder for the aggregates. The aggregates used are usually coarse gravel or crushed rocks, such as limestone, or granite, along with fine aggregates. Many admixtures are used to achieve various and different properties. At last water is added to this dry mixture which helps in providing shape, make it solid and give strength. The process of hardening and strengthening with the help of chemical reaction is called hydration. Water reacts with cement and makes a bond with other material, making a very hard stone like material. Concrete is good in compression and bad in tension, so reinforcements are added to concrete. Concrete structures break to some degree, because of shrinkage and tension. It is most suitable for building as it is durable, fire resistant and gain more strength over time. Now-a-days, to get high strength concrete we use admixture to make it economic and efficient. As we know the concrete is a flexible construction material. Firstly, it was introduced as a protective cover of steel members, after that it was improved and now days it is consumed as a structural member and to modify its properties steel is provided and it gives greater strength to concrete. It was noticed that as compared to Steel the normal concrete have many weakness like as low value of strength to weight ratio. So as to reduce this weakness resulted in the development of high strength concrete (HSC). Presently, with over the top utilization of admixtures and broadly conveyed use of innovation in concrete technology it is anything but difficult to accomplish chamber quality $50 \mathrm{MPa}$ in 12 to 18 hours \& close to $70 \mathrm{MPa}$ or above at 28 days. 


\section{MATERIAL AND DESIGN METHODOLOGY}

High Strength Concrete It is a term used to define concrete with the main properties not attributed to the normal concrete. Its cube strength lies between 60 to $100 \mathrm{~N} / \mathrm{mm}^{2}$. With the use of local materials this strength is not easy to acquire. Therefore the selection of the materials is required to achieve the High Strength Concrete.

- The development of HSC will require Ordinary Portland cement of 53 grades to get better workability and strength. The various physical properties are required for cement to be used in HSC are:-

- Maximum Blaine fineness $\mathrm{cm}^{2} / \mathrm{gm}$

Maximum 7 day cube strength $\mathrm{MPa}$

Marble Dust with the development and advancement in the field of new technologies with artificial and waste material the burden on utilization of natural resources is significantly reduced. The mechanical properties can be improved by the alternative use of materials which significantly improve properties of concrete by replacing it with sand. The alternative material which is being used is waste marble dust. The marble dust has been generally used as a building material. It is produced during sawing and shaping of marbles. Dumping material elsewhere cause environmental pollution. Therefore utilization of waste material also contributes towards reducing environmental problem. This project focuses on investigating the probability of using marble dust as a partial replacement of sand by weight in the concrete.
Steel Fibers Reinforced Concrete: Fibers reinforced concrete comprises of combination of four different systems, like cement, water, coarse aggregates, fine aggregates and dispersion of discontinuous, steel fibers. Admixture and pozzolans may also be added to the system of conservative concrete. Under the ASTM specifications all the admixtures are used in concrete desirable for use in Steel Fibers reinforced concrete (SFRC).

\section{Typical practical ranges of fibers reinforcement of concrete}

\begin{tabular}{|c|c|c|}
\hline $\begin{array}{c}\text { Approx. Vol. } \\
\text { Fraction of } \\
\text { Fibers }\end{array}$ & Matrix & Example \\
\hline $\mathrm{V}_{\mathrm{f}}<0.5 \%$ & Concrete & PP in pipe caps \\
\hline $\begin{array}{c}0.5<\mathrm{V}_{\mathrm{f}}< \\
3 \%\end{array}$ & $\begin{array}{c}\text { Concrete } \\
\text { (smaller size } \\
\text { agg.) }\end{array}$ & Pavements, Joints \\
\hline $3<\mathrm{V}_{\mathrm{f}}<8 \%$ & Mortar & $\begin{array}{c}\text { Cement sheets, } \\
\text { repairs }\end{array}$ \\
\hline $\begin{array}{c}8<\mathrm{V}_{\mathrm{f}}< \\
20 \%\end{array}$ & Paste, Slurry & $\begin{array}{c}\text { Asbestos cement } \\
\text { sheets, slurry }\end{array}$ \\
\hline
\end{tabular}

Chemical and Physical Properties of Cement and Marble dust: Chemical Properties and Physical properties of both Ordinary Portland Cement (OPC) and Marble Dust (MD) were studied by various scientists as shown in Table

\section{Chemical Composition limits of Portland cement}

\begin{tabular}{|c|c|c|c|}
\hline $\begin{array}{c}\text { Chemical Composition } \\
(\% \text { by mass })\end{array}$ & $\begin{array}{c}\text { Bahar Demirel } \\
(\mathbf{2 0 1 0})\end{array}$ & $\begin{array}{c}\text { G.D.Dhawale } \text { et } \\
\text { al. (2014) }\end{array}$ & $\begin{array}{c}\text { Alyamac et al. } \\
\text { (2015) }\end{array}$ \\
\hline Alumina $\left(\mathrm{Al}_{2} \mathrm{O}_{3}\right)$ & 5.62 & $3.0-8.0$ & 5.34 \\
\hline Calcium oxide $(\mathrm{CaO})$ & 62.94 & $60-67$ & 62.62 \\
\hline Iron oxide $\left(\mathrm{Fe}_{2} \mathrm{O}_{3}\right)$ & 3.24 & $0.5-6.0$ & 4.03 \\
\hline Magnesium oxide $(\mathrm{MgO})$ & 2.73 & $0.1-4.0$ & 2.05 \\
\hline
\end{tabular}


International Journal of Trend in Scientific Research and Development, Volume 1(4), ISSN: 2456-6470 www.ijtsrd.com

\begin{tabular}{|c|c|c|c|}
\hline Sulphur trioxide $\left(\mathrm{SO}_{3}\right)$ & - & - & 2.69 \\
\hline Silicon Dioxide $\left(\mathrm{SiO}_{2}\right)$ & 21.12 & $17-25$ & 19.45 \\
\hline Specific gravity, $\mathrm{g} / \mathrm{cm}^{3}$ & 3.10 & 3.15 & - \\
\hline
\end{tabular}

\section{Physical Properties of OPC}

\section{Physical Composition $\quad$ Bahar Demirel (2010) $\quad$ G.D.Dhawale et al. (2014)}

Specific gravity, $\mathrm{g} / \mathrm{cm}^{3}$

3.10

3.15

\section{EXPERIMENTAL PROGRAMMES}

\section{Cement}

Physical properties of Ordinary Portland cement (OPC)

\begin{tabular}{|c|c|c|c|}
\hline Sr. No. & Characteristics & $\begin{array}{l}\text { Experimental } \\
\text { value }\end{array}$ & $\begin{array}{l}\text { Values as per } \\
\text { IS: 12269-1987 }\end{array}$ \\
\hline 1. & $\begin{array}{c}\text { Standard } \\
\text { consistency }(\%)\end{array}$ & 29 & - \\
\hline 2. & $\begin{array}{l}\text { Initial Setting time } \\
\text { (min) }\end{array}$ & 120 & 30 (minimum) \\
\hline 3. & $\begin{array}{l}\text { Final Setting time } \\
\text { (min) }\end{array}$ & 185 & 600 (maximum) \\
\hline 4. & Specific Gravity & 3.15 & - \\
\hline 5. & Fineness & 0.097 & $0.1 \%$ \\
\hline \multirow[t]{4}{*}{6.} & \multicolumn{3}{|c|}{ Compressive Strength ( $1: 3)$} \\
\hline & 3 Days & $45.21 \mathrm{~N} / \mathrm{mm}^{2}$ & $33.71 \mathrm{~N} / \mathrm{mm}^{2}$ \\
\hline & 7 Days & $54.82 \mathrm{~N} / \mathrm{mm}^{2}$ & $46.32 \mathrm{~N} / \mathrm{mm}^{2}$ \\
\hline & 28 Days & $69.32 \mathrm{~N} / \mathrm{mm}^{2}$ & $58.82 \mathrm{~N} / \mathrm{mm}^{2}$ \\
\hline
\end{tabular}


International Journal of Trend in Scientific Research and Development, Volume 1(4), ISSN: 2456-6470 www.ijtsrd.com

\section{Mixture Proportioning}

Mix proportions of various Mixes

\begin{tabular}{|c|c|c|c|c|c|c|c|c|c|}
\hline $\begin{array}{c}\text { HSC } \\
\text { Mixes }\end{array}$ & $\begin{array}{c}\text { Cement } \\
\left(\mathrm{kg} / \mathrm{m}^{3}\right)\end{array}$ & $\begin{array}{c}\text { FA } \\
\left(\mathrm{kg} / \mathrm{m}^{3}\right)\end{array}$ & $\begin{array}{c}\text { MID } \\
(\%)\end{array}$ & $\begin{array}{c}\text { MD } \\
\left(\mathrm{kg} / \mathrm{m}^{3}\right)\end{array}$ & $\begin{array}{c}\text { CA } \\
\left(\mathrm{kg} / \mathrm{m}^{3}\right)\end{array}$ & SF (\%) & $\begin{array}{c}\text { Water } \\
\left(\mathrm{kg} / \mathrm{m}^{3}\right)\end{array}$ & w/c & SP (\%) \\
\hline Mix 1 & 555.96 & 500 & 0 & 0 & 1169.89 & 0 & 172.32 & 0.31 & 1 \\
\hline Mix 2 & 555.96 & 425 & 15 & 75 & 1169.89 & 0.8 & 172.32 & 0.31 & 1 \\
\hline Mix 3 & 555.96 & 350 & 30 & 150 & 1169.89 & 0.8 & 172.32 & 0.31 & 1 \\
\hline Mix 4 & 555.96 & 275 & 45 & 225 & 1169.89 & 0.8 & 172.32 & 0.31 & 1 \\
\hline Mix 5 & 555.96 & 200 & 60 & 300 & 1169.89 & 0.8 & 172.32 & 0.31 & 1 \\
\hline
\end{tabular}

\section{Flexural Strength}

Flexural Strength of various HSC mixes

\begin{tabular}{|c|c|c|c|c|}
\hline \multirow{2}{*}{$\begin{array}{l}\text { HSC } \\
\text { Mixes }\end{array}$} & \multicolumn{2}{|c|}{7 Days } & \multicolumn{2}{|c|}{28 Days } \\
\hline & $\begin{array}{c}\text { FS } \\
\left(\mathrm{N} / \mathbf{m m}^{2}\right)\end{array}$ & $\begin{array}{l}\text { Avg. FS } \\
\left(\mathrm{N} / \mathrm{mm}^{2}\right)\end{array}$ & $\begin{array}{c}\text { FS } \\
\left(\mathrm{N} / \mathrm{mm}^{2}\right)\end{array}$ & $\begin{array}{l}\text { Avg. FS } \\
\left(\mathrm{N} / \mathrm{mm}^{2}\right)\end{array}$ \\
\hline \multirow[t]{3}{*}{ Mix 1} & 7.43 & \multirow[t]{3}{*}{7.33} & 8.32 & \multirow[t]{3}{*}{8.21} \\
\hline & 7.32 & & 8.05 & \\
\hline & 7.24 & & 8.28 & \\
\hline \multirow[t]{3}{*}{ Mix 2} & 8.4 & \multirow[t]{3}{*}{8.38} & 9.84 & \multirow[t]{3}{*}{9.82} \\
\hline & 8.52 & & 9.76 & \\
\hline & 8.22 & & 9.86 & \\
\hline \multirow[t]{3}{*}{ Mix 3} & 8.15 & \multirow[t]{3}{*}{8.12} & 9.34 & \multirow[t]{3}{*}{9.46} \\
\hline & 8.25 & & 9.40 & \\
\hline & 7.93 & & 9.64 & \\
\hline \multirow[t]{3}{*}{ Mix 4} & 8.05 & \multirow[t]{3}{*}{7.82} & 8.66 & \multirow[t]{3}{*}{8.53} \\
\hline & 7.86 & & 8.37 & \\
\hline & 7.55 & & 8.56 & \\
\hline \multirow[t]{3}{*}{ Mix 5} & 5.95 & \multirow[t]{3}{*}{5.95} & 6.02 & \multirow[t]{3}{*}{6.23} \\
\hline & 6.08 & & 6.35 & \\
\hline & 5.82 & & 6.32 & \\
\hline
\end{tabular}




\section{CONCLUSION}

This study was attempted to investigate the flexural strength, split tensile strength and compressive strength of concrete with various level of replacement of sand with marble dust and with the addition of steel fiber content. Sand was partly replaced by marble dust i.e. $0 \%, 15 \%, 30 \%, 45 \%, 60 \%$ and also steel fibers were added at percentage of $0.8 \%$ in all the batches. Super plasticizer "BASF- PCE BASE 50" was used in all HSC mixes at $1 \%$ by the weight of the cement. Current research shows that the physical and mechanical of concrete improves with the addition of waste materials.

\section{Fresh Concrete Properties}

The HSC mixes have a slump flow lying in the range $500-700 \mathrm{~mm}$. With the increase of waste materials the slump decreased. The concrete workability is inversely proportional to the content of marble powder. However, it is worthwhile to know that the required workability of the concrete is possible to achieve with $\&$ without chemical additives.

\section{Compressive Strength}

The compressive strength increased up to $45 \%$ replacement, after that strength started decreasing. With lower w/c ratio, the use of marble dust as sand replacement proved to be more effective. The highest increment was at $45 \%$ replacement of marble dust and added $0.8 \%$ of steel fiber nearly $9 \%$ at 28 days of curing. After $45 \%$ replacement there was decrement in compressive strength because marble dust shows pozzolonic property due to which it affects the properties of cement.

\section{Split Tensile Strength}

The curve and bar chart of split tensile strength test shows that the split tensile strength of the concrete increased up to $15 \%$, after that started decreasing. The w/c ratio remained constant i.e. 0.31 for all mixes. Increase in the cohesiveness of the material due to lower fineness modulus of the marble dust so it increases the split tensile strength. The highest increment was at $15 \%$ of marble dust and $0.8 \%$ of steel fiber nearly gave $4 \%$ at 28 days of curing.

\section{Flexural Strength}

The curve and the bar chart of the flexural strength test shows that the flexural strength of the concrete increased up to $15 \%$, after that started decreasing. The highest increment was at $15 \%$ replacement of the marble dust and added $0.8 \%$ of steel fiber nearly gave $20 \%$ at 28 days of curing. The increase in flexural strength of concrete is due to the lower fineness modulus which provides cohesiveness property to the material.

\section{REFERENCES}

[1] Demirel, Bahar. (2010). The effect of using waste marble dust as fine sand on the mechanical properties of concrete. International Journal of the Physical Sciences 5.9: 1372-1380.

[2] IS: 4031 (Part 4, 5\&6)-1988: Methods of Physical Tests for Hydraulic Cement, Bureau of Indian Standard, New Delhi (India)

[3] IS: 383-1970: Specification for coarse and fine aggregates from natural sources for concrete, Bureau of Indian standard, New Delhi (India)

[4] IS: 516 (1959) Indian standard code of practice- methods of tests for strength of concrete, Bureau of Indian standard, New Delhi (India)

[5] IS: 5816 (1999) Methods of test for splitting tensile strength of concrete, Bureau of Indian standard, New Delhi (India)

[6] ASTM C1585 (2007) Standard test method for measurement of rate of absorption of water by hydraulic-cement concretes

[7] Hameed M., Sekar S. (2009). Properties of green concrete containing quarry rock dust and marble sludge powder as fine aggregates. India, ARPN Journal of Engineering and Applied Sciences 4 (4) 83-89

[8] Heboub H., Aoun H., Belacia M., Houari H., Gorbel E. (2010). Use of waste marble aggregates in concrete. Construction and Building Material 25: 1167-1171

[9] Sirulea P.A. (2012). Partial replacement of cement wit marble dust powder, International Journal of Advanced Engineering Research and Studies E-IISN 2249-897 